\title{
Antibodies of Patients with Lyme Disease to Components of the Ixodes dammini Spirochete
}

\author{
Alan G. Barbour, Department of Health and Human Services, Public Health \\ Service, National Institutes of Health, National Institute of Allergy and \\ Infectious Diseases, Laboratory of Microbial Structure and Function, Rocky \\ Mountain Laboratories, Hamilton, Montana 59840 \\ Willy Burgdorfer, Epidemiology Branch, Rocky Mountain Laboratories, \\ Hamilton, Montana 59840 \\ Edgar Grunwaldt, 44 South Ferry Road, Shelter Island, New York 11964 \\ Allen C. Steere, Department of Internal Medicine, Yale University School of \\ Medicine, New Haven, Connecticut 06510
}

\begin{abstract}
A B S T RACT Lyme disease is an inflammatory disorder of skin, joints, nervous system, and heart. The disease is associated with a preceding tick bite and is ameliorated by penicillin treatment. A spirochete (IDS) isolated from Ixodes dammini ticks has been implicated as the etiologic agent of Lyme disease. We examined the antibody responses of Lyme disease patients to IDS lysate components in order to further understand the pathogenesis of this disease. The components were separated by sodium dodecyl sulfatepolyacrylamide gel electrophoresis, transferred to nitrocellulose, reacted with patients' sera, and the bound IgG was detected with ${ }^{125}$ I-labeled protein A (western blot). We found that (a) Lyme disease patients had antibodies to IDS components $(b)$ most patients studied had antibodies to two components with apparent subunit molecular weights of 41,000 and 60,000 , and (c) the patients' antibody responses during illness and remission were specific, for the most part, for the IDS. In contrast to the findings with Lyme disease sera, sera from controls showed little reactivity with IDS components in either the western blots or a derivative solidphase radioimmunoassay.
\end{abstract}

\section{INTRODUCTION}

Lyme disease, a seasonal inflammatory disorder, has been reported from the United States, Europe, and Australia (1-4). In the United States, most patients

Received for publication 26 November 1982 and in revised form 20 April 1983. have acquired the disease during the summer in areas along the northeastern seaboard, in Wisconsin and Minnesota, or in Oregon and California $(5,6)$. The most specific manifestation of Lyme disease is erythema chronicum migrans (ECM), ${ }^{1}$ an expanding annular skin lesion accompanied by fever, headache, and myalgias $(7,8)$. In a typical Lyme disease case, the initial ECM lesion is followed, after an interval lasting a few days or a few months, by involvement of the joints, nervous system, and/or heart (8). The arthritis in its early phase is most commonly pauciarticular and relapsing; in some patients, it may progress to a chronic arthritis that has the histologic characteristics of rheumatoid arthritis (9). The nervous system involvement is usually characterized by a meningoencephalitis, cranial neuritis, and/or radiculoneuritis that are fluctuating in degree (10). A minority of patients may also, or instead, develop high degree heart block (11). In general, the arthritic complications appear later and last longer than the neurologic and cardiac sequelae (8).

The seasonality of the disorder $(1,5,6)$, the clustering of cases (1), the apparent transmission of ECM via inoculations of skin lesion samples (12), and the amelioration of Lyme disease with antibiotics (13)

\footnotetext{
${ }^{1}$ Abbreviations used in this paper: DPT, diazophenylthioether; ECM, erythema chronicum migrans; IDS, Ixodes dammini spirochete; IFA, indirect immunofluorescenceassay; NC, nitrocellulose; PAGE, polyacrylamide gel electrophoresis; TSGAN, $50 \mathrm{mM}$ Tris (pH 7.4), $150 \mathrm{mM} \mathrm{NaCl,} 5 \mathrm{mM}$ EDTA, $0.25 \%$ gelatin, $0.05 \%$ sodium azide, $0.05 \%$ Nonidet.
} 
have suggested an infectious etiology. There is evidence, however, that the host's immune response to the infectious agent may also be important in the pathogenesis of Lyme disease. The majority of acutely ill patients have circulating immune complexes and cryoglobulins $(14,15)$, and the neurologic and cardiac manifestations resemble those of serum sickness and rheumatic fever, respectively $(10,11)$.

The association of Lyme disease with a preceding ixodid tick bite or with residence in an area with a high density of ixodid ticks has been established (5, $16,17)$. We have previously proposed that a hitherto unknown spirochete, which was isolated from the ixodid tick Ixodes dammini, is the etiologic agent of Lyme disease (18). Subsequent isolations of similar, if not identical, spirochetes from Lyme disease patients support this proposal $(19,20)$. In addition, we found that rabbits fed upon by spirochete-infected $I$. dammini ticks developed ECM-like skin lesions $(18,21)$.

In the present study, we addressed the following questions: (a) Against what components of the I. dammini spirochete (IDS) do Lyme disease patients have antibodies? (b) Are elevated concentrations of antibodies to IDS components specific for Lyme disease patients? $(c)$ Are the antibody responses of Lyme disease patients specific for IDS components?

\section{METHODS}

Strains and culture conditions. The I. dammini spirochete strain B31, originally isolated from ticks collected on Shelter Island, NY (18), was cloned by limiting dilution and then passaged in Barbour, Stoenner, Kelly (BSK) medium, a modification of fortified Kelly's medium $(18,22,23)$. Batch cultures of B31 were made in glass tissue culture bottles (Gibco Laboratories, Grand Island, NY) that had been rinsed with glass-distilled water, autoclaved, and filled with $533 \mathrm{ml}$ of warm BSK medium. Each bottle was inoculated with 8 $\mathrm{ml}$ of a late log-phase culture, tightly capped, and incubated at $35^{\circ} \mathrm{C}$ for $4-5 \mathrm{~d}$. The final density of organisms was $0.5-$ $1.0 \times 10^{8} / \mathrm{ml}$. The cells were harvested by centrifugation $\left(10,000 \mathrm{~g}\right.$ for $20 \mathrm{~min}$ at $\left.20^{\circ} \mathrm{C}\right)$. The pellet was resuspended in a $1 / 50$ vol of $M / 15$ phosphate-buffered saline (PBS) with $5 \mathrm{mM} \mathrm{MgCl} 2$ (PBS/Mg) and $15 \%$ (vol/vol) glycerol. The suspension was kept at $-76^{\circ} \mathrm{C}$.

Other bacterial species examined (and their sources if other than author A.G.B.) were: Rickettsia rickettsii (R. Anacker, Rocky Mountain Laboratories), Chlamydia psittaci (H. Caldwell, Rocky Mountain Laboratories), Leptospira interrogans (G. Schmid, Centers for Disease Control, Atlanta), Treponema phagedenis (A.T.C.C. 27087), Borrelia hermsii strain HSl (24), Escherichia coli, and Pseudomonas aeruginosa. The last two strains were clinical isolates.

Sera. Human sera were obtained from several sources: (a) 11 patients at the Yale-New Haven Medical Center who had Lyme disease (8). They were bled at different times in the course of their illnesses (Table I and Fig. 2). We included patient $D$ in the study because her sera had not shown antiIDS reactivity in preliminary immunofluorescence assays. (b) 10 patients at Yale-New Haven Medical Center who had other rheumatic disorders (Table II and Fig. 3; controls 1-
10) were included; $(c)$ six residents of Shelter Island, NY, without history of ECM or Lyme disease (Table II and Fig. 3; controls 11-17); (d) 14 Shelter Island residents with Lyme disease (included were patients J.S., C.T., B.B., L.H., C.G., and J.G. of reference 18); (e) a patient with ECM from Strasbourg, France (serum provided by A. Aeschlimann, University of Neuchâtel, Switzerland); $(f)$ a Wisconsin resident with Lyme disease (serum provided by J. P. Davis, Department of Health and Social Services, Madison, WI); (g) a patient with Lyme disease acquired in California (serum provided by P. E. Lavoie, San Francisco, CA); and $(h)$ a patient with Lyme disease acquired in Rhode Island (serum provided by J. B. Houpt, Toronto, Ontario). Table II summarizes the remainder of control sera; the residence, if known, of persons from whom blood was drawn; the illness, if any, of these persons; and the source of the sera, if other than one of the authors.

Adult New Zealand white rabbits that had been fed upon by spirochete-infected $I$. dammini ticks and that had subsequently developed ECM-like skin lesions $(18,21)$ were bled 10-12 wk after the tick feedings.

Indirect immunofuorescence assay (IFA). Human sera were examined for antibodies against methanol-fixed B31 organisms by IFA, as described (24). The fluorescinated goat anti-human globulin serum (BBL Microbiology Systems, Becton-Dickinson and Co., Cockeysville, MD) was used in a 1:200 dilution of $1 \%$ bovine serum albumin (BSA) in PBS. The criterion for a positive reaction was fluorescence of spirochetes that was greater than the background staining of rat erythrocytes on the smear. The presence or absence of fluorescent blebs on the spirochetes was also noted during the assays.

Polyacrylamide gel electrophoresis (PAGE). Frozen spirochetes were thawed, centrifuged for $3 \mathrm{~min}$ in a microfuge (Beckman Instruments, Inc., Irvine, CA), and washed three times with cold $\mathrm{PBS} / \mathrm{Mg}$. After the last centrifugation, cells were suspended in a volume of distilled water to give an $\mathrm{OD}_{595}$ of 0.2 when the cell suspension was analyzed for protein content by the Bradford method (25). Sample buffer was added to the cells in water for final concentrations of $1 \%$ sodium dodecyl sulfate (SDS; British Drug Houses, Ltd., Poole, Dorset, England) and 10\% 2-mercaptoethanol. The samples were boiled for $5 \mathrm{~min}$, and $25 \mu \mathrm{l}(\sim 15 \mu \mathrm{g}$ of protein) was subjected to SDS-PAGE as described by Laemmli and Favre (26). The pH of the separating gel buffer was 8.6 , and the acrylamide concentration was $10 \%$. Tris base was obtained from Research Organics, Inc., Cleveland, OH. Gels were stained with Coomassie Brilliant Blue R-250 or by the silver stain method of Switzer et al. (27) as modified by P. J. Hitchcock and T. M. Brown (paper submitted for publication). Molecular weight standards labeled with ${ }^{14} \mathrm{C}$ were phosphorylase $B(93,000)$, bovine albumin $(69,000)$, ovalbumin $(46,000)$, carbonic anhydrase $(30,000)$, and beta lactoglobulin (18,000) (New England Nuclear, Boston, MA).

Labeling of spirochetes with radioactive iodine. Washed and thawed spirochetes were labeled with ${ }^{125} I$ in the presence of 1,3,4,6-tetrachloro-3 $\alpha, 6 \alpha$-diphenylglycoluril (Iodogen; Pierce Chemical Co., Rockford, IL) by a modification of the method of Markwell and Fox (28). The modification has been described (24). The spirochetes were in a suspension in PBS/ $\mathrm{Mg}$ that had a protein content of $0.3 \mathrm{mg} / \mathrm{ml}$ by the Bradford assay (25). The labeled preparations were examined by SDSPAGE as described above. The gels were dried and radioautography was performed on the dried gels with Kodak XOmat AR or TL film (Eastman Kodak Co., Rochester, NY). Electrophoretic transfer of separated proteins from SDSPAGE to nitrocellulose (NC) and application of antibody 
to the blots. The procedure used for performing transfer of proteins from SDS-PAGE gels to NC and incubation of blots with sera (western blot) was a modification of the methods of Towbin et al. (29) and Renart et al. (30). The proteins in a gel were transferred to NC (HAHY; Millipore Corp., Bedford, MA) in a Trans-Blot cell (Bio-Rad Laboratories, Richmond, CA) containing $192 \mathrm{mM}$ glycine, $26 \mathrm{mM}$ Tris base, and $20 \%$ methanol. The cell was kept at $25^{\circ} \mathrm{C}$ with a cooling coil during electrophoresis $(60 \mathrm{~V}$ for $3 \mathrm{~h})$. After electrophoresis, the NC blots were blocked by overnight incubation in heat-sealable plastic bags containing 2\% BSA (fraction V; Miles Laboratories, Elkhart, IN) in $50 \mathrm{mM}$ Tris (pH 7.4 ), $150 \mathrm{mM} \mathrm{NaCl}, 5 \mathrm{mM}$ EDTA, $0.25 \%$ gelatin (Knox Gelatine, Inc., Englewood Cliffs, NJ), 0.05\% sodium azide, and $0.05 \%$ Nonidet P-40 (TSGAN) (31). We incubated the blots in plastic tubes containing a 1:100 dilution of human or rabbit sera in 2\% BSA/TSGAN for $2 \mathrm{~h}$ at room temperature. The strips were then washed three times with TSGAN. The blots were incubated with ${ }^{125}$ I-labeled protein A $\left(5 \times 10^{5}\right.$ $\mathrm{cpm} / \mathrm{ml}$ TSGAN) for $1 \mathrm{~h}$ at room temperature. Protein $\mathrm{A}$ (Pharmacia Fine Chemicals, Division of Pharmacia Inc., Piscataway, $\mathrm{NJ}$ ) had been labeled by a modification of the chloramine-T method of Hunter and Greenwood (32) to a specific activity of $5 \mu \mathrm{Ci} / \mu \mathrm{g}$. The blots were washed four times with TSGAN, rinsed several times with water, dried, and placed on X-ray film. AR and TL films were exposed for 14$24 \mathrm{~h}$ and $2-4 \mathrm{~d}$, respectively.

Solid phase radioimmunoassay (RIA). Thawed and washed spirochetes were lysed in $0.1 \%$ SDS in $50 \mathrm{mM}$ sodium phosphate buffer, $\mathrm{pH}$ 6.2. The suspension was centrifuged $\left(51,000 \mathrm{~g}\right.$ for $60 \mathrm{~min}$ at $\left.20^{\circ} \mathrm{C}\right)$. The supernatant volume was adjusted with $0.1 \%$ SDS in the phosphate buffer to give a protein content of $0.2 \mathrm{mg} / \mathrm{ml}$ by the Bradford assay (25). The lysyl, tyrosyl, and histidinyl residues of proteins in the solution were reacted with diazonium groups on diazophenylthioether (DPT) paper that was prepared by the method attributed to B. Seed (33). Whatman 540 paper (Whatman Inc., Clifton, NJ) was the cellulose substrate for activation. The activated paper was reacted with the lysate solution for $3 \mathrm{~h}$ at $21^{\circ} \mathrm{C}$ in heat-sealable bags on a rocker. The remaining diazonium groups were blocked by incubation of the paper with $100 \mathrm{mM}$ Tris, $\mathrm{pH} 9.0,10 \%$ ethanolamine, and $0.25 \%$ gelatin (30) overnight at room temperature. The paper was then washed several times with water and dried. With a paper punch, we cut $6.4-\mathrm{mm}$ diameter disks from the paper and stored them in a desiccator at $4^{\circ} \mathrm{C}$ for up to 4 mo before use. Before the $0.1 \%$ SDS-soluble proteins of ${ }^{125}$ I-labeled IDS (see above) in the reaction mixture, we estimated in preliminary studies that each disk had $150 \mathrm{ng}$ of IDS protein that was not removed by several washes with $2 \%$ SDS.

At the time of the assay, disks were placed in a flat bottom, 96-well, polystyrene microliter plate (Linbro, Falcon Plastics, Oxnard, CA) and covered with 2\% BSA/TSGAN for 30 min. After aspiration of this solution, twofold dilutions of human or rabbit sera in $2 \%$ BSA/TSGAN in $100-\mu$ l volumes were placed in wells. The plates were incubated for $60 \mathrm{~min}$ at $37^{\circ} \mathrm{C}$. The solutions were aspirated, and the wells were washed three times with TSGAN. ${ }^{125}$ I-labeled protein $A$ in TSGAN was incubated with the disks $\left(5 \times 10^{4} \mathrm{cpm} /\right.$ well $)$ for $30 \mathrm{~min}$ at $37^{\circ} \mathrm{C}$. After aspirating the labeled protein A solution, we washed the disks four times with TSGAN that contained $0.5 \%$ Nonidet $\mathrm{P}-40$. The disks were then rinsed several times with water, dried, removed from the plates, and counted in a gamma counter (Beckman Instruments, Inc., Irvine, CA). The assays were performed in duplicate. A serum dilution was considered positive if the mean counts per minute bound by DPT disks with IDS components was either threefold higher or $1,000 \mathrm{cpm}$ higher than the mean counts per minute bound at the same serum dilution to DPT disks that had been prepared as described above, except that there were no IDS components in the SDS and phosphate buffer. The radioactivity associated with IDS disks or control disks that had been incubated with $2 \%$ BSA/TSGAN alone or with greater than $1: 2,560$ dilutions of sera was between 200 and $300 \mathrm{cpm}\left(0.4-0.6 \%\right.$ of added ${ }^{125} \mathrm{I}$-protein A) per disk.

\section{RESULTS}

IFA. The Lyme disease patients and the controls are described in Tables I and II. Also listed are IFA results. All Lyme disease patients except $D$ had one or more serum samples with a reciprocal titer $\geq 80$. Among 41 control sera, only five (12\%) had titers $\geq$ 80: two patients with active rheumatic disorders other than Lyme disease (controls 4 and 6), and three patients with syphilis (controls 37,38 and 39 ). Although the syphilitic patients had titers up to 320 , the staining of the spirochetes was relatively weak even at low dilutions and the syphilitics' sera, in contrast to Lyme disease sera, never highlighted spirochetal blebs. Control sera 4 and 6 at low dilutions could not be distinguished from sera from patients with Lyme disease by IFA.

SDS-PAGE. The proteins of IDS whole cell lysates were separated by SDS-PAGE and identified with western blots, Coomassie Blue stain, silver stain, and ${ }^{125}$ I-labeling (Fig. 1). In the western blot, several components were bound by IgG in Lyme disease serum H3. No bands were seen when the blot was incubated with only ${ }^{125}$ I-protein A (data not shown). The blot reactions with control sera are described below. 10 components in the $\mathrm{H} 3$ serum blot that were associated with intensely emitting bands and that were clearly identifiable in repeat blots were arbitrarily numbered 1 to 10 (Fig. 1). The apparent subunit molecular weights $\left(\times 10^{3}\right)$ for these components were, in order from 1 to 10: 17, 25, 29, 31, 41, 60,61, 66, 75, and 83 . In the Coomassie Blue-stained gel, proteins with the same apparent molecular weights as 4 through 10 were identified. In the silver-stained gel, in which the darkness of a component's staining is not necessarily related to its concentration in the sample (34), we saw numerous bands, many of which had the same apparent molecular weights as the western blot components. The locations of some of these are shown. Many components were also seen in the ${ }^{125}$ I-labeled preparation of B31. Of note was the relatively greater labeling of proteins with the same apparent molecular weights as components 3,5 , and 8 , and the lesser labeling of component 4 , which was, with component 5 , the most darkly stained proteins with Coomassie Blue.

Western blots. These studies indicated to us that the majority, if not all, of the bands in the H3 serum 
TABLE I

Summary of Connecticut Lyme Disease Patient Sera

\begin{tabular}{|c|c|c|c|c|}
\hline Serum & $\begin{array}{c}\text { Days after } \\
\text { onset }\end{array}$ & Clinical status & $\begin{array}{l}\text { Reciprocal } \\
\text { IFA titer }\end{array}$ & $\begin{array}{c}\text { Reciprocal } \\
\text { RIA titer }\end{array}$ \\
\hline Al & 10 & $\mathrm{ECM}$ & 80 & - \\
\hline 2 & 20 & Convalescence & 40 & - \\
\hline Bl & 21 & ECM & 40 & - \\
\hline 2 & 57 & Convalescence & 320 & - \\
\hline $\mathrm{Cl}$ & 18 & ECM & 160 & 40 \\
\hline 2 & 88 & Active neurologic disease & 160 & 2,560 \\
\hline 3 & 186 & Resolving neurologic disease & 80 & 1,280 \\
\hline 4 & 1,104 & Remission & 320 & - \\
\hline D1 & 1 & ECM & $<10$ & $<20$ \\
\hline 2 & 45 & Active neurologic disease & $<10$ & - \\
\hline 3 & 268 & Active neurologic disease & $<10$ & - \\
\hline 4 & 438 & Active neurologic disease & $<10$ & $<20$ \\
\hline El & 18 & ECM & 10 & $<20$ \\
\hline 2 & 29 & Active neurologic disease & 20 & - \\
\hline 3 & 137 & Active arthritis & 320 & 640 \\
\hline 4 & 411 & Resolving arthritis & 40 & - \\
\hline F1 & 14 & ECM & 80 & 80 \\
\hline 2 & 142 & Active neurologic disease & 160 & - \\
\hline 3 & 185 & Active arthritis & 1,280 & 10,240 \\
\hline 4 & 434 & Resolving arthritis & 320 & 一 \\
\hline Gl & 31 & ECM & 40 & - \\
\hline 2 & 70 & Convalescent ECM & 160 & - \\
\hline 3 & 121 & Active arthritis & 320 & - \\
\hline 4 & 179 & Resolving arthritis & 40 & 一 \\
\hline H1 & 12 & ECM & 160 & 40 \\
\hline 2 & 78 & Active arthritis & 320 & - \\
\hline 3 & 92 & Resolving arthritis & 1,280 & 20,480 \\
\hline 4 & 245 & Resolving arthritis & 640 & - \\
\hline Il & 31 & $\mathbf{E C M}$ & 160 & - \\
\hline 2 & 51 & Active arthritis & 320 & - \\
\hline 3 & 93 & Active arthritis & 320 & - \\
\hline 4 & 335 & Resolving arthritis & 320 & - \\
\hline $\mathrm{Jl}$ & 10 & ECM & $<10$ & $<20$ \\
\hline 2 & 367 & Convalescent ECM & 320 & - \\
\hline 3 & 410 & Active arthritis & 640 & - \\
\hline 4 & 712 & Resolving arthritis & 1,280 & 1,280 \\
\hline $\mathbf{K} \mathbf{1}$ & 18 & ECM & $<10$ & $<20$ \\
\hline 2 & 35 & Convalescent ECM & 40 & - \\
\hline 3 & 591 & Active arthritis & 320 & - \\
\hline 4 & 800 & Resolving arthritis & 640 & 20,480 \\
\hline
\end{tabular}

western blot could be identified as B31 lysate components. We then examined sera from other patients with Lyme disease (Fig. 2) and sera from controls (Fig. 3).
Among patients A-K, only patient $\mathrm{D}$ showed no detectable reactivity with IDS components in blots. Patient A, who had been treated for ECM and did not develop sequelae, had detectable antibodies to lysate 
material that did not leave the stacking gel (location shown by arrows in Fig. 2). The remaining patients, all of whom had neurologic and/or arthritic manifes- tations and had been followed for months to years after onset of their diseases, had IgG antibodies that bound to one or more B31 components. The solid triangle in

TABLE II

Summary of Control Sera

\begin{tabular}{|c|c|c|c|}
\hline Serum & Disease (residence) & $\begin{array}{l}\text { Reciprocal } \\
\text { IFA titer }\end{array}$ & $\begin{array}{c}\text { Reciprocal } \\
\text { RIA titer }\end{array}$ \\
\hline 1 & Rheumatoid arthritis (Connecticut) & 20 & - \\
\hline 2 & Polymyositis (Connecticut) & 40 & - \\
\hline 3 & Rheumatoid arthritis (Connecticut) & $<10$ & - \\
\hline 4 & Rheumatoid arthritis (Connecticut) & 80 & $<20$ \\
\hline 5 & Psoriatic arthritis (Connecticut) & 10 & - \\
\hline 6 & Rheumatoid arthritis (Connecticut) & 80 & $<20$ \\
\hline 7 & Rheumatoid arthritis (Connecticut) & 40 & - \\
\hline 8 & Rheumatoid arthritis (Connecticut) & $<10$ & - \\
\hline 9 & Systemic lupus (Connecticut) & $<10$ & - \\
\hline 10 & Systemic lupus (Connecticut) & 40 & $<20$ \\
\hline 11 & None (Long Island) & $<20$ & - \\
\hline 12 & None (Long Island) & $<20$ & - \\
\hline 13 & None (Long Island) & $<20$ & - \\
\hline 14 & None (Long Island) & 40 & - \\
\hline 15 & None (Long Island) & 40 & - \\
\hline 16 & Juvenile rheumatoid arthritis (Long Island) & $<20$ & - \\
\hline 17 & None (Long Island) & $<20$ & - \\
\hline 18 & None (Switzerland) ${ }^{\circ}$ & $<20$ & - \\
\hline 19 & None (Switzerland) ${ }^{\bullet}$ & $<20$ & - \\
\hline 20 & Scleroderma (Switzerland) ${ }^{\circ}$ & $<20$ & - \\
\hline 21 & None (Maryland) $\downarrow$ & 40 & - \\
\hline 22 & None (Maryland) $!$ & 20 & - \\
\hline 23 & None (Montana) & $<20$ & - \\
\hline 24 & None (Montana) & $<20$ & - \\
\hline 25 & None (Montana) & $<20$ & - \\
\hline 26 & None (Montana) & $<20$ & - \\
\hline 27 & None (Montana) & $<20$ & - \\
\hline 28 & None (Montana) & 20 & - \\
\hline 29 & Polyarteritis nodosa (Montana) & $<10$ & - \\
\hline 30 & Toxic shock syndrome, conval. (Montana) & $<20$ & - \\
\hline 31 & None (Montana) & $<10$ & - \\
\hline 32 & Rocky Mountain spotted fever, conval. (North Carolina) & 10 & - \\
\hline 33 & None (California) $\S$ & $<20$ & - \\
\hline 34 & None (California) $\S$ & $<20$ & - \\
\hline 35 & Leptospirosis, conval. (Montana) & $<10$ & $<20$ \\
\hline 36 & Relapsing fever, conval. (Colorado) & $<10$ & $<20$ \\
\hline 37 & Secondary syphilis (Georgia)" & 80 & - \\
\hline 38 & Secondary syphilis (Georgia)" & 320 & $<20$ \\
\hline 39 & Early latent syphilis (Montana) $\pi$ & 320 & $<20$ \\
\hline 40 & Relapsing fever, conval. (Washington) & $<20$ & - \\
\hline 41 & Congenital syphilis, treated (Montana) & $<20$ & - \\
\hline
\end{tabular}

- Dr. A. Aeschlimann, Zoological Institute, University of Neuchâtel, Neuchâtel, Switzerland.

$\downarrow$ Dr. R. A. Kaslow, Epidemiology and Biometry Section, National Institute of Allergy and Infectious Diseases, National Institutes of Health, Bethesda, MD.

§ Dr. P. E. Lavoie, 2300 California Street, San Francisco, CA.

" Dr. G. P. Schmid, Special Pathogens Branch, Center for Infectious Diseases, Centers for Disease Control, Atlanta, GA.

I Dr. D. Abbott, State Department of Health, Helena, MT. 


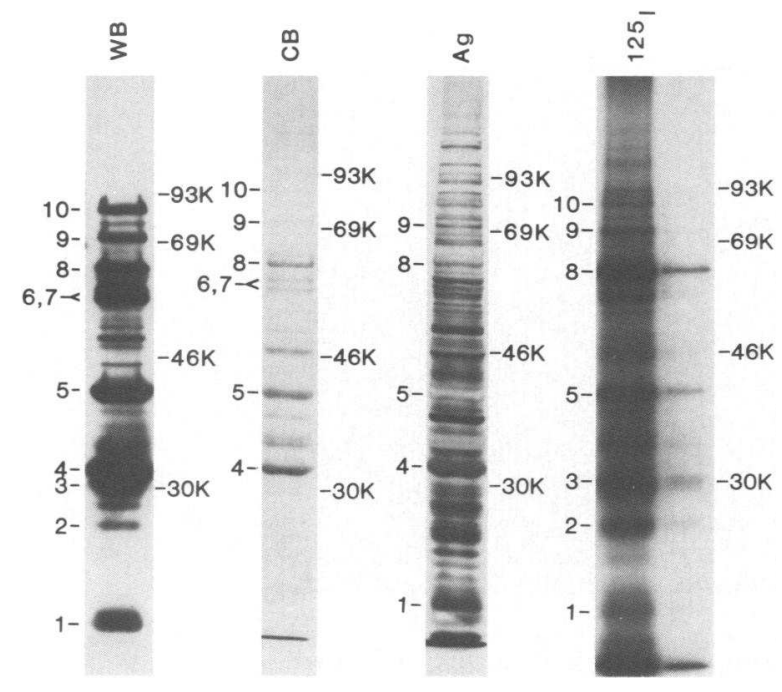

Figure 1 SDS-PAGE of whole cell lysates of IDS strain B31 In western blots (WB), PAGE-separated components were transferred to NC and reacted with serum; the blots were probed for bound IgG with ${ }^{125}$ I-labeled protein A. Kodak XOmat AR film was exposed to the blots for $16 \mathrm{~h}$. The middle two lanes show gels stained with either Coomassie Blue $(C B)$ or silver stain $(A g)$. IDS cells were also radioiodine-labeled in the presence of Iodogen $\left({ }^{125} I\right)$. Radioautographs of the PAGE of the lysed, labeled organisms and a 1:10 dilution (far right) are shown. Kodak X-Omat TL film was exposed to dried gels for $24 \mathrm{~h}$. The locations of ${ }^{14} \mathrm{C}$-labeled molecular weight standards (see text) in each gel or blot are shown. 10 IDS components were numbered in WB. Similarly migrating bands in the other lanes $\left(C B, A g\right.$, and $\left.{ }^{125} I\right)$ are indicated.

Fig. 2 points to the approximate location of component 5 in the radioautographs. Patients B, C, F, G, and I, like patient $A$, had detectable antibodies to material that did not leave the stacking gel. The apparent amount and diversity of antibodies to IDS components were less during the initial stages of the disorder than later. In patients $\mathrm{C}$ and $\mathrm{E}$, both the apparent amount and diversity of antibodies also decreased during remission.

In contrast to Lyme disease patient sera, few controls had antibody that detectably bound to IDS components in western blots. The five controls that did were 15, who was from Shelter Island and may have had an inapparent infection; 36, who was convalescing from $B$. hermsii relapsing fever; 38 , who had secondary syphilis; 39 , who had untreated early latent syphilis; and 41 , an adult with treated congenital syphilis. Fig. 3 indicates the components recognized by each of these control sera. Controls 38 and 39 had antibody to material remaining in the stacking gel. Control 4 , who had active rheumatoid arthritis, had serum that produced a very dark background in the radioautograph.

We also examined western blots of single-serum samples from Shelter Island Lyme disease patients and from Lyme disease or ECM patients from Wisconsin, France, California, and Rhode Island. Molecular weight standards and serum H3 were included in each set of blots derived from one gel. The patterns produced with individual serum from patients from Shelter Island and other locations were similar to those of Connecticut patient sera. An accounting of bands in these blots as well as those shown in Fig. 2 (patients B, C, and E-K) was performed. All patients had antibody that bound to components 5 and 6.25 (93\%) of the 27 sera also contained IgG that bound components 8 and 10. Only $12(37 \%)$ of the patients had detectable antibody to component 4 , a protein that was abundant in whole cell lysates but was poorly labeled with iodine (Fig. 1).

We also compared the reactions of Lyme disease patient sera in blots to those of rabbits that had been fed upon by infected I. dammini ticks and who had subsequently developed skin lesions that resembled ECM. Blots using sera from three of these rabbits (3050, 3092, and 3093) and serum from control rabbit who had been fed upon by Dermacentor variabilis ticks are shown in Fig. 4. Although the rabbits had antibodies to components that were not generally recognized by human sera, many of the 10 components were recognized by the rabbits with ECM-like lesions. The $D$. variabilis control rabbit serum shown in the figure, as well as other control rabbit sera not shown, did not contain IgG that detectably bound to any IDS component.

Because of the possibility that Lyme disease patients had elevated antibodies against IDS components in western blots as a result of polyclonal B cell stimulation, we examined the reactivity of serum $\mathrm{H} 3$ to components of several other bacteria. These include $P$. aeruginosa, $R$. rickettsii, T. phagedenis, L. interrogans, B. hermsii, C. psittaci, and E. coli. In Fig. 5, the panel on the left shows the Coomassie Blue-stained proteins in SDS lysates of these bacteria. The panels in the middle and on the right are the radioautographs of blots using sera $\mathrm{H} 1$ and $\mathrm{H} 3$ and serum from control 6 . The blots were exposed to film twice as long as blots shown in Figs. 2 and 3. Patient $\mathrm{H}$ had antibodies to components in every bacterial species examined in both acute and convalescent sera. Although there were detectable increases in binding to substances in the other spirochetes (L. interrogans, T. phagedenis, and $B$. hermsii), the major changes between sera $\mathrm{Hl}$ and $\mathrm{H} 3$ were clearly in antibodies to the IDS components. 


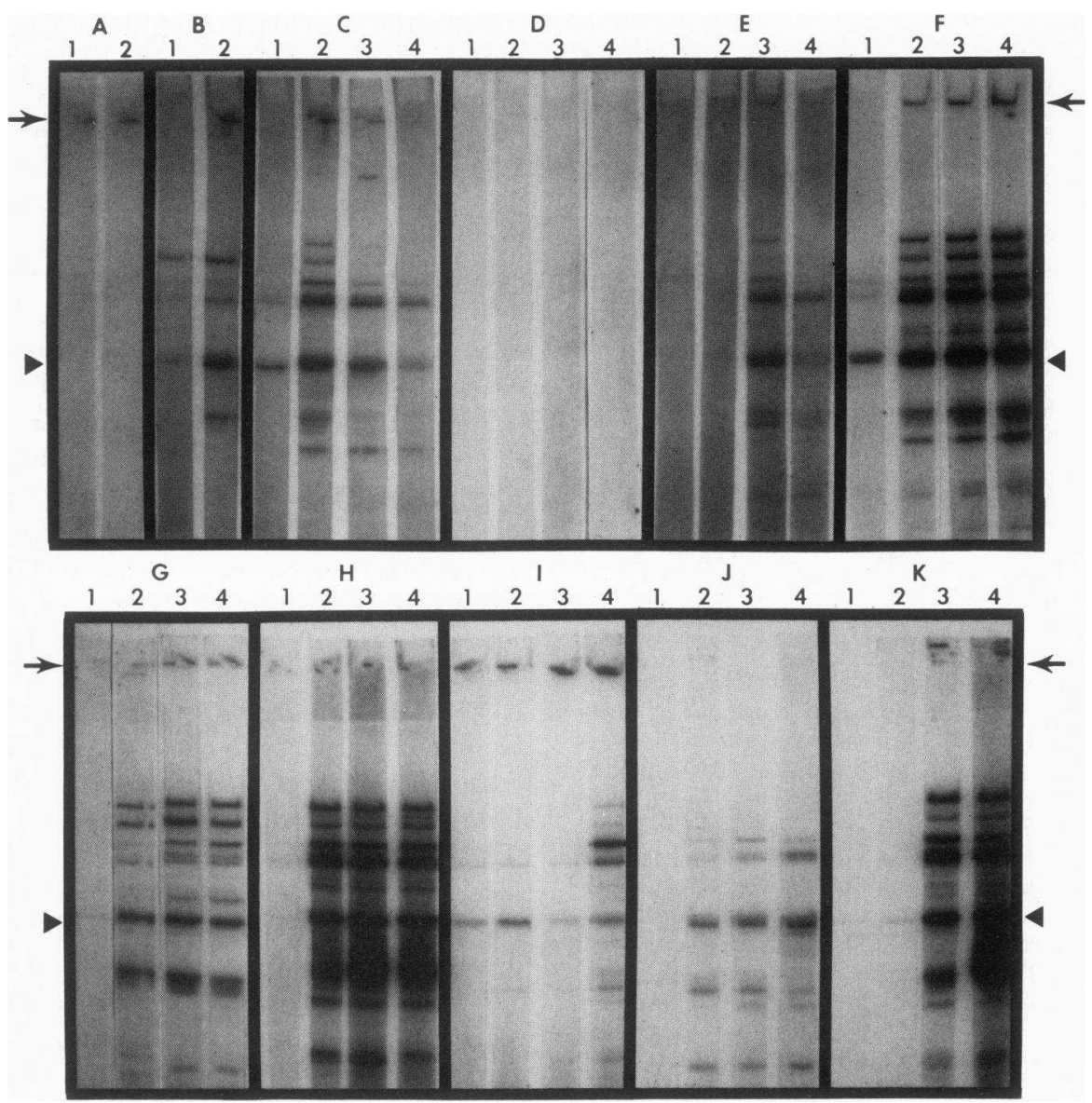

FIGURE 2 Western blot analysis of sera from Lyme disease patients A-K. Methods are described in text and in legend of Fig. 1. The different lanes of the blots were incubated with dilutions of sera identified in Table I. The arrow indicates the bottom of the stacking gel slot. The triangle indicates the approximate location of component 5 in the blots. Patients B, C, and E-K had IgG in their sera that detectably bound to component 5. Kodak X-Omat TL film was exposed for $2 \mathrm{~d}$.

Control 6 had detectable antibodies to components of $\dot{P}$. aeruginosa, R. rickettsii, C. psittaci, and E. coli. Similar, relatively weak reactivities to components of these bacteria were shown by other control sera that were examined.

Solid-phase RIA. A solid phase RIA was designed to quantitatively estimate the IgG response to SDSextractable proteins that had been qualitatively demonstrated by western blot analysis. The presumed advantage of DPT paper for a RIA was that, in contrast to NC, proteins could be covalently bound to the solidphase matrix and bound in the presence of SDS $(30$, $33,35)$. When selected Lyme disease and control sera were examined in this way, we found that the Lyme disease patients had elevated titers (Tables I and II).
The titers rose between early and later serum samples. Controls who had elevated IF A titers or who had some anti-IDS component antibodies by western blot analysis were negative by the criteria described. We also calculated, for a serum dilution of 1:160, the net radioactivity associated with the IDS disks, i.e., the counts per minute for the IDS disks minus counts per minute for the blank disks. The mean counts per minute \pm SE for patient sera C2, E3, F3, H3, and J4 in the assays was $4,741 \pm 1,360$. The mean counts per minute \pm SE for control sera $4,6,10,35,36,38$, and 39 was $232 \pm 105$. Patient D's sera did not show reactivity by this test as well. A rabbit (3050) with ECM-like lesions and the D. variabilis control rabbit (see Fig. 4) had RIA titers of $1: 10,240$ and $<1: 20$, respectively. The 

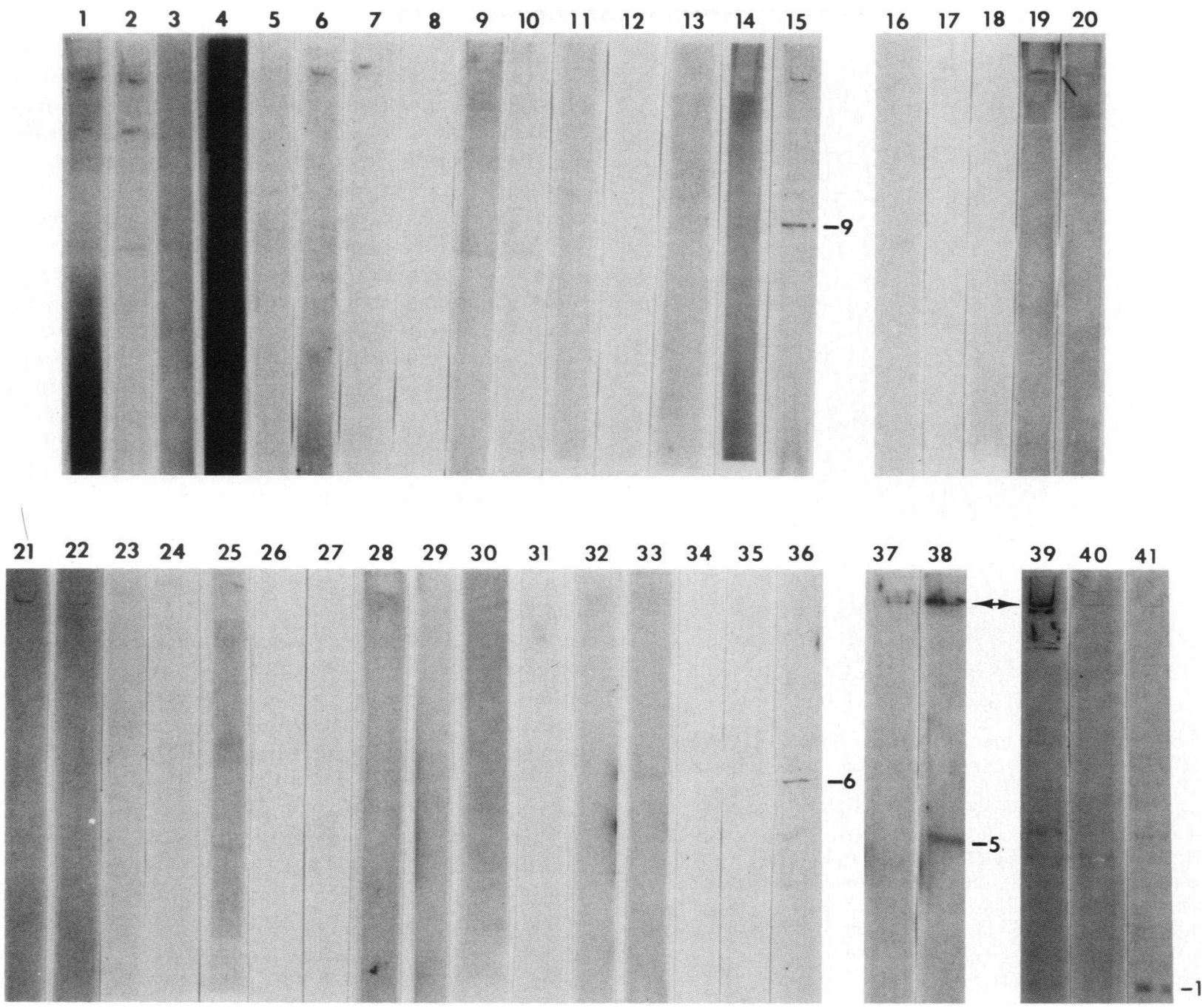

Figure 3 Western blot analysis of control sera 1-41 (Table II). Methods described in text and in legend of Fig. 1. The numbers correspond to similarly migrating IDS components identified in Fig. 1. The arrow indicates radioactivity at the bottom of the stacking gel slot. Kodak XOmat TL film was exposed for $2 \mathrm{~d}$.

semiquantitative results obtained with western blots approximated the results obtained with the RIA.

\section{DISCUSSION}

This study together with the reports of isolations of IDS spirochetes from humans $(19,20)$ provide further evidence that the ixodid tick-borne spirochetes are the etiologic agents of Lyme disease. It is still possible, however, that anti-IDS antibodies and even spirochetemia are only markers for Lyme disease, and that the actual disease-inducing agent is another microor- ganism co-introduced with the IDS. Until Lyme disease can be induced in humans or experimental animals by introduction of purified spirochetes, this possibility cannot be absolutely discounted. The morbidity associated with complicated Lyme disease discourages human experimentation. Therefore, work is under way on possible animal models.

Although many controls were from a Lyme diseaseendemic area and/or had other rheumatic diseases, an estimate of the true prevalence of anti-IDS antibodies in these populations awaits seroepidemiologic studies. Nonetheless, it appears that detectable antibody to any 


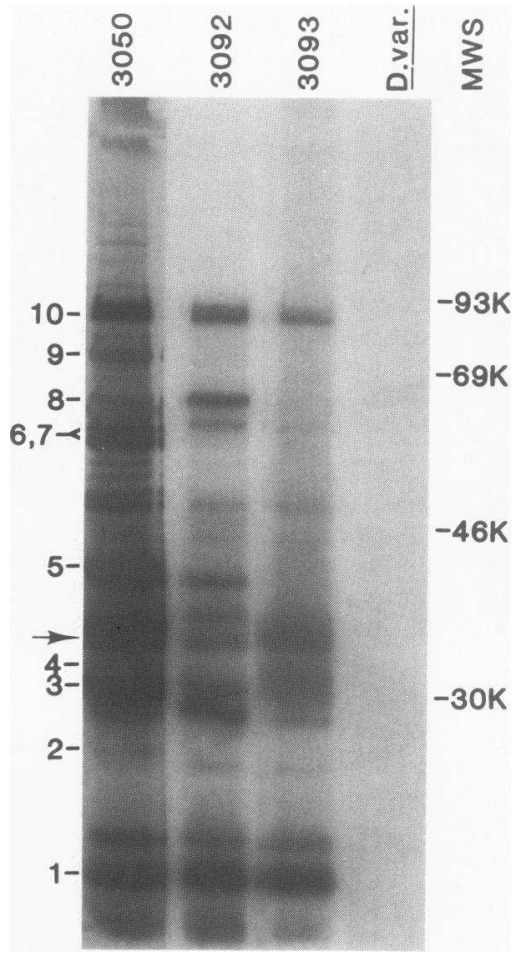

Figure 4 Western blot analysis of rabbit sera. Methods described in text and in legend of Fig. 1. Sera from rabbits 3050,3092 , and 3093, who where fed upon by spirocheteinfected I. damminiticks and subsequently developed ECMlike lesions, were compared with serum from a rabbit who had been fed upon by $D$. variabilis ticks. The numerals correspond to the IDS components identified in Fig. 1. The arrow indicates an IDS component that was recognized by 3050,3092 , and 3093 sera but seldom by human sera. Kodak $\mathrm{X}$-Omat AR film was exposed for $16 \mathrm{~h}$.

IDS component, in western blots at least, is uncommon both in persons without Lyme disease and in patients in the disease's early phase.

The immunofluorescence results and western blot/ RIA results may not be comparable. We may have detected anti-IDS IgM and $\operatorname{IgG}_{3}$ with the IFA. This was not possible with western blots, inasmuch as ${ }^{125} \mathrm{I}$ protein $A$ binds only to human $\operatorname{IgG}_{1}, \operatorname{IgG}_{2}$, and $\operatorname{IgG}_{4}$ (36). Whereas the IFA focused, for the most part, on surface-exposed antigens, the western blot examined one-dimensionally separated components of the entire organism. In spite of the inherent differences in the methods, there was considerable concordance between the IFA and western blot/RIA results. We found that, in general, the IFA was less specific than the RIA. The sera from controls $4,6,10$, and 38 exemplified this point.
The western blot and the derivative RIA do not allow detection of antibodies to IDS components that are not bound by NC or DPT paper or which have irreversibly altered epitopes after exposure to SDS, 2-mercaptoethanol, and boiling. The western blot performed under conditions described here permits analysis of epitopes contained in the primary structure of proteins. Aware of these constraints in the methodology, we made additional conclusions from the results.

Individual humans and rabbits do not seem to respond immunologically to an IDS in exactly the same way. We also observed different patterns of IDS components that were recognized by Lyme disease patients vs. rabbits with ECM-like lesions. At this point, there is not an obvious relationship between the western blot profile and the type and degree of illness, except for the observation that sera from arthritis patients contained antibodies to more IDS components than sera from patients with ECM alone or with neurologic involvement. Patients with arthritis also, on average, have higher antibody titers to the IDS by IFA (19). The finding that patients developed arthritis and/or neurologic disease while possessing anti-IDS antibodies may be relevant to Lyme disease pathogenesis. These antibodies may not be capable of neutralizing the infection. Alternatively, they may be, as constituents of circulating immune complexes or as cross-reacting autoantibodies (37), a factor in the progression to arthritis and/or neurologic disease.

There were two Connecticut Lyme disease patients, A and D, who had both low or negative titers by IFA and few or no bands by western blot. Perhaps patient D was not capable of responding to the IDS with IgG or had another neurologic disorder. Patient A had ECM, which was treated with antibiotics. The second serum was drawn only $20 \mathrm{~d}$ after onset. Sera from patients $\mathrm{E}$ and $\mathrm{K}$ also warrant comment. Patient $\mathrm{E}$ had an IFA titer of 20 and only faintly visible bands on western blot with serum drawn $29 \mathrm{~d}$ after onset of ECM. Patient K's early sera were similar. We have noted in other cases that the interval between onset of disease and detection by IFA of elevated IgG antibody titers to the IDS may be relatively long and that titer elevations are often small in promptly treated patients (19; unpublished observations, W. Burgdorfer and A. G. Barbour).

There were two IDS components to which all patients except $A$ and $D$ had antibody: components 5 and 6. Component 5 was an abundant protein in Coomassie Blue-stained gels and in labeled preparations of the IDS. Component 5 may be useful as an immunodiagnostic reagent. Enthusiasm may be tempered, however, by the observations that a secondary syphilis patient had antibody to a component with the same ap- 

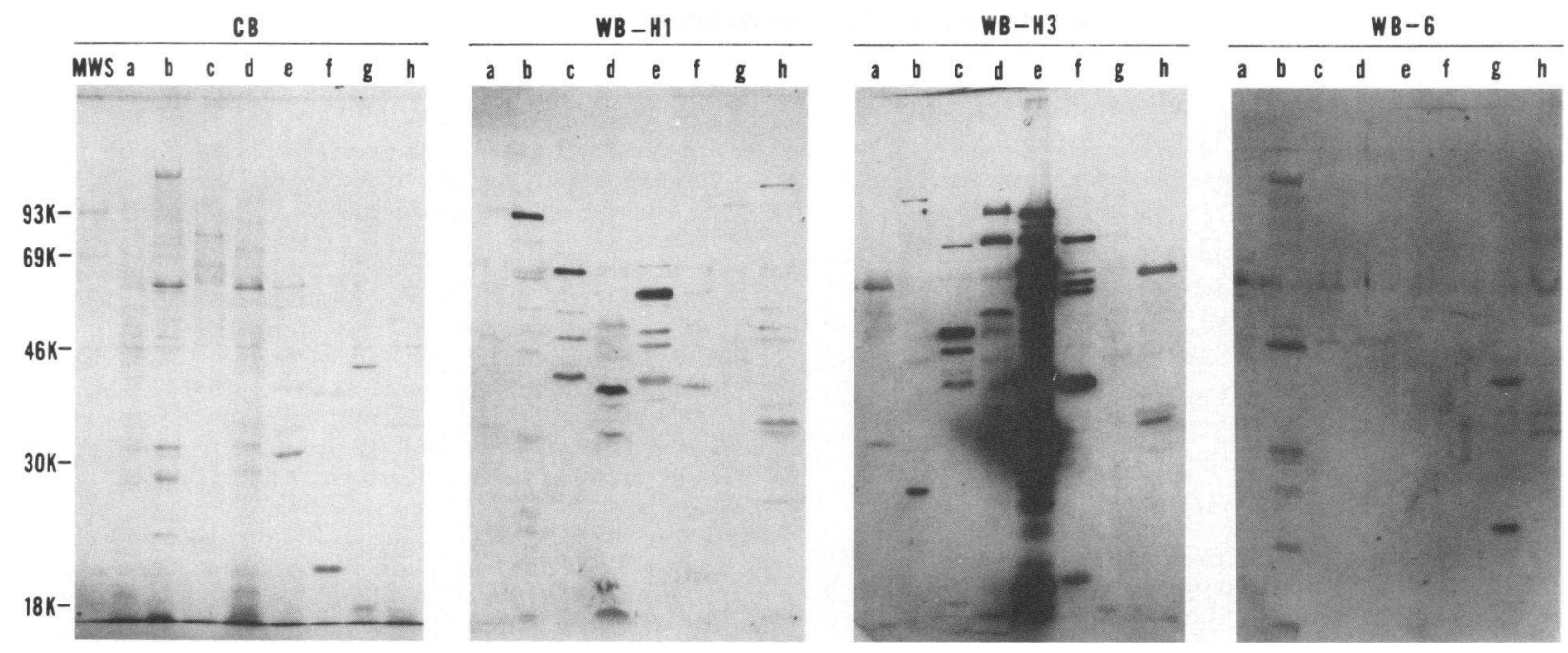

Figure 5 PAGE of various bacteria and western blots with representative Lyme disease and control sera. Methods described in text and in legend of Fig. 1. PAGE was performed on whole cell lysates of the following bacterial species: (a) P. aeruginosa, (b) R. rickettsii, (c) T. phagedenis, (d) L. interrogans, (e) IDS, $(f) B$. hermsii, $(g) C$. psittaci, and $(h) E$. coli. The sera used were $\mathrm{Hl}$ and $\mathrm{H} 3$ (Table I) and control 6 (Table II). The panel on the left shows the Coomassie Blue-stained proteins $(C B)$. The panels in the middle and on the right are the radioautographs of western blots $(W B)$. The location of molecular weight standards $(M W S)$ are shown on the left. Kodak X-Omat TL film was exposed for $4 \mathrm{~d}$.

parent molecular weight as 5 (Fig. 3) and that rabbits immunized with $B$. hermsii, an agent of tick-borne relapsing fever, had antibodies to component 5 of IDS in western blots (unpublished observations, A. G. Barbour). With regard to component 6 , one of the controls who had relapsing fever had antibody to this or a similarly migrating component. A second person with syphilis had antibody to component 1 . IDS components 1,5 , and 6 may be proteins that share conserved amino acid sequences with functionally analogous proteins of T. pallidum and the relapsing fever borreliae. Cognizant of these antigenic cross-reactions, minor though they may be, we could argue that the so-called antiIDS antibodies of Lyme disease patients merely are evidence of remote infections with other spirochetes. These patients may, indeed, have had prior exposure to a spirochete, perhaps one of the ubiquitous oral treponemes. Nevertheless, the recovery of IDS-like spirochetes from patients during acute illness $(19,20)$ and the evolution of IgM and IgG antibody responses during the course of Lyme disease $(19,20$, present study) does indicate that an IDS-like spirochete infection is contemporaneous with Lyme disease.

Other examples of antigenic cross-reactivities between a treponeme, a borrelia, a leptospire, and the IDS were seen in Fig. 5. In the same figure are generally fainter bands in PAGE lanes containing more distantly related bacterial genera, such as Pseudomonas and Rickettsia. Although we cannot rule out nonimmune binding or sticking of IgG molecules in patient H's and control 6's sera to these bacterial components, we suspect that these persons probably did have immunoglobulins that bound to these components via antigen-recognition sites. These antibodies, which were apparently in lower concentration and/or of lower affinity compared to the anti-IDS antibodies of patient $\mathrm{H}$, may have resulted from remote infections or colonizations with these or related species. Alternatively, they may result from spontaneous or background immunoglobulin synthesis (38). In any case, the sensitivity of western blot analysis appears to necessitate use of antigen controls, such as the distantly related bacteria used in this study, as well as serum controls.

We identified several other IDS components against which Lyme disease patients had antibodies. Additional to components that entered the separating gel was the material that did not leave or may not have even entered the stacking gel. The nature of this apparently SDS-insoluble material, against which some patients with Lyme disease and patients with syphilis had antibody, is unknown. It is possible that it is spirochetal peptidoglycan, a material that would not enter the gel. 
The similar western blot patterns in patients who acquired their diseases in Connecticut, New York, Rhode Island, Wisconsin, California, and France were evidence that these spirochetes cause Lyme disease and ECM in other areas besides the northeastern United States. The similar patterns also suggest that if ixodid tick-borne spirochetes are isolated from these other locations, we may find considerable antigenic relatedness between these spirochetes. Indeed, a spirochete isolated from I. ricinus ticks of Switzerland was similar in its PAGE profile and its immunofluorescence reactions to IDS $\mathrm{B} 31(21,22)$.

\section{ACKNOWLEDGMENTS}

We thank Sandy Tessier for expert technical assistance; Dr. Penny Hitchcock for help with the silver stain; Drs. Abbott, Aeschlimann, Anacker, Caldwell, Davis, Houpt, Kaslow, Lavoie, and Schmid for providing strains or sera; the staff of the Laboratory of Microbial Structure and Function for their critical reviews of the manuscript; Chuck Taylor and Bob Evans for photographic work; and Susan Smaus for preparation of the manuscript.

\section{REFERENCES}

1. Steere, A. C., S. E. Malawista, D. R. Snydman, R. E Shope, W. A. Andiman, M. R. Ross, and F. M. Steele. 1977. Lyme arthritis: an epidemic of oligoarticular arthritis in children and adults in three Connecticut communities. Arthritis Rheum. 20:7-17.

2. Illouz, G., and J. Hewitt. 1981. À propos de l'arthrite de Lyme: Polyarthrite inflammatoire après un érythème annulaire migrant. Rev. Rheum. Mal. Osteo-artic. 48:813-815.

3. Gerster, J. C., J. Guggi, H. Perroud, and R. Bovet. 1981. Lyme arthritis appearing outside the United States: a case report from Switzerland. British Med. J. 283:951952 .

4. Stewart, A., J. Glass, A. Patel, G. Watt, A. Cripps, and R. Clancy. 1982. Lyme arthritis in Hunter Valley. Med. J. Australia. 1:139.

5. Steere, A. C., and S. E. Malawista. 1979. Cases of Lyme disease in the United States: locations correlated with distribution of Ixodes dammini. Ann. Intern. Med. 91:730-733.

6. Centers for Disease Control. 1982. Lyme Disease. Morbidity and Mortality Weekly Report. 31:367-368.

7. Afzelius, A. 1921. Erythema chronicum migrans. Acta Dermato-Venereol. 2:120-125.

8. Steere, A. C., S. E. Malawista, J. A. Hardin, S. Ruddy, P. W. Askenase, and W. A. Andiman. 1977. Erythema chronicum migrans and Lyme arthritis: The enlarging clinical spectrum. Ann. Intern. Med. 86:685-698.

9. Steere, A. C., A. Gibofsky, M. E. Patarroyo, R. J. Winchester, J. A. Hardin, and S. E. Malawista. 1979. Chronic Lyme arthritis: clinical and immunogenetic differentiation from rheumatoid arthritis. Ann. Intern. Med. 90:286-291.

10. Reik, L., A. C. Steere, N. H. Bartenhagen, R. E. Shope, and S. E. Malawista. 1979. Neurologic abnormalities of Lyme disease. Medicine (Baltimore). 58:281-294.
11. Steere, A. C., W. P. Batsford, M. Weinberg, J. Alexander, H. J. Berger, S. Wolfson, and S. E. Malawista. 1980. Lyme carditis: cardiac abnormalities of Lyme disease. Ann. Intern. Med. 93:8-16.

12. Binder, E., R. Doepfmer, and O. Hornstein. 1955. Übertragung des erythema chronicum migrans von mensch zu mensch in zwei passagen. Klin. Wochenshr. 33:727728.

13. Steere, A. C., S. E. Malawista, J. H. Newman, P. N. Spieler, and N. H. Bartenhagen. 1980. Antibiotic therapy in Lyme disease. Ann. Intern. Med. 93:1-8.

14. Hardin, J. A., L. C. Walker, A. C. Steere, T. C. Trumble, K. S. K. Tung, R. C. Williams, Jr., S. Ruddy, and S. E. Malawista. 1979. Circulating immune complexes in Lyme arthritis. Detection by the ${ }^{125} \mathrm{I}-\mathrm{Clq}$ binding, $\mathrm{Clq}$ solid phase, and Raji cell assays. J. Clin. Invest. 63:468477.

15. Steere, A. C., J. A. Hardin, S. Ruddy, J. G. Mummaw, and S. E. Malawista. 1979. Lyme arthritis: correlation of serum and cryoglobulin IgM with activity, and serum IgG with remission. Arthritis Rheum. 22:471-483.

16. Steere, A. C., T. F. Broderick, and S. E. Malawista. 1978. Erythema chronicum migrans and Lyme arthritis: epidemiologic evidence for a tick vector. Am. J. Epidemiol. 108:312-321.

17. Wallis, R. C., S. E. Brown, K. O. Kloter, and A. J. Main. 1978. Erythema chronicum migrans and Lyme arthritis: field study of ticks. Am. J. Epidemiol. 108:322-327.

18. Burgdorfer, W., A. G. Barbour, S. F. Hayes, J. L. Benach, E. Grunwaldt, and J. P. Davis. 1982. Lyme disease-A tick-borne spirochetosis?Science (Wash. DC). 216:13171319.

19. Steere, A. C., R. L. Grodzicki, A. N. Kornblatt, J. E. Craft, A. G. Barbour, W. Burgdorfer, G. P. Schmid, E. Johnson, and S. E. Malawista. 1983. The spirochetal etiology of Lyme disease. N. Engl. J. Med. 308:733-740.

20. Benach, J. L., E. M. Bosler, J. P. Hanrahan, J. L. Coleman, G. S. Habicht, T. F. Bast, D. J. Cameron, J. L. Ziegler, A. G. Barbour, W. Burgdorfer, R. Edelman, and R. A. Kaslow. 1983. Spirochetes isolated from the blood of two patients with Lyme disease. N. Engl. J. Med. 308:740-742.

21. Burgdorfer, W., A. G. Barbour, S. F. Hayes, O. Peter, and A. Aeschlimann. 1983. Erythema chronicum migrans: a tick-borne spirochetosis. Acta Trop. 40:79-83.

22. Barbour, A. G., W. Burgdorfer, S. F. Hayes, O. Peter, and A. Aeschlimann. 1983. Isolation of a cultivable spirochete from Ixodes ricinus ticks of Switzerland. Curr. Microbiol. 8:123-126.

23. Stoenner, H. G., T. Dodd, and C. Larsen. 1982. Antigenic variation of Borrelia hermsii. J. Exp. Med. 156:1297-1311.

24. Barbour, A. G., S. L. Tessier, and H. G. Stoenner. 1982. Variable major proteins of Borrelia hermsii. J. Exp. Med. 156:1312-1324.

25. Bradford, M. M. 1976. A rapid and sensitive method for the quantitation of microgram quantities of protein utilizing the principle of protein-dye binding. Anal. Biochem. 72:248-254.

26. Laemmli, U. K., and M. Favre. 1973. Maturation of the head of bacteriophage T4. 1. DNA packing events. $J$. Mol. Biol. 80:575-599.

27. Switzer III, R. C., C. R. Merril, and S. Shifrin. 1979. A highly sensitive silver stain for detecting proteins and peptides in polyacrylamide gels. Anal. Biochem. 98:231237. 
28. Markwell, M. A., and C. F. Fox. 1978. Surface-specific iodination of membrane proteins of viruses and eucaryotic cells using 1,3,4,6-tetrachloro-3 $\alpha, \alpha$-diphenylglycoluril. Biochemistry. 17:4807-4817.

29. Towbin, H., T. Staehelin, and J. Gordon. 1979. Electrophoretic transfer of proteins from polyacrylamide gels to nitrocellulose sheets: procedure and some applications. Proc. Natl. Acad. Sci. USA. 76:4350-4354.

30. Renard, J., J. Reiser, and G. R. Stark. 1979. Transfer of proteins from gels to diazobenzyloxymethyl-paper and detection with antisera: a method for studying antibody specificity and antigen structure. Proc. Natl. Acad. Sci. USA. 76:3116-3120.

31. Kessler, S. W. 1975. Rapid isolation of antigens from cells with a staphylococcal Protein A-antibody absorbent: parameter of the interaction of antibody-antigen complexes with Protein A. J. Immunol. 115:1617-1624.

32. Hunter, W. M., and F. C. Greenwood. 1962. Preparation of iodine-131 labeled human growth hormone of high specific activity. Nature (Lond.). 194:495-496.

33. Reiser, J., and J. Wardale. 1980. Sensitive immunological detection of translation products in SV40 plaques. Gene (Amst.). 12:11-16.
34. Guevara, Jr., J., D. A. Johnston, L. S. Ramagali, B. A. Martin, S. Capetillo, and L. V. Rodriguez. 1982. Quantitative aspects of silver deposition in proteins resolved in complex polyacrylamide gels. Electrophoresis. 3:197205.

35. Symington, J., M. Green, and K. Brachmann. 1981. Immunoautographic detection of proteins after electrophoretic transfer from gels to diazo-paper: analysis of adenovirus encoded proteins. Proc. Natl. Acad. Sci. USA. 78:177-181.

36. Langone, J. J. 1982. Protein A of Staphylococcus aureus and related immunoglobulin receptors produced by streptococci and pneumococci. Adv. Immunol. 32:157252.

37. Wood, J. N., L. Hudson, T. M. Jessell, and M. Yamamoto. 1982. A monoclonal antibody defining antigenic determinants on subpopulations of mammalian neurones and Trypanosoma cruzi parasites. Nature (Lond.). 296:3438.

38. Benner, R., A. van Oudenaren, J. J. Haaijman, J. Slingerland-Teunissen, B. S. Wostman, and W. Hijmans. 1981. Regulation of the "spontaneous" (background) immunoglobulin synthesis. Int. Arch. Allergy Appl. Immunol. 66:404-415. 